\title{
Geniculate quadruple sectoranopia
}

\section{Benjamin J. Osborne, MD; Grant T. Liu, MD; and Steven L. Galetta, MD}

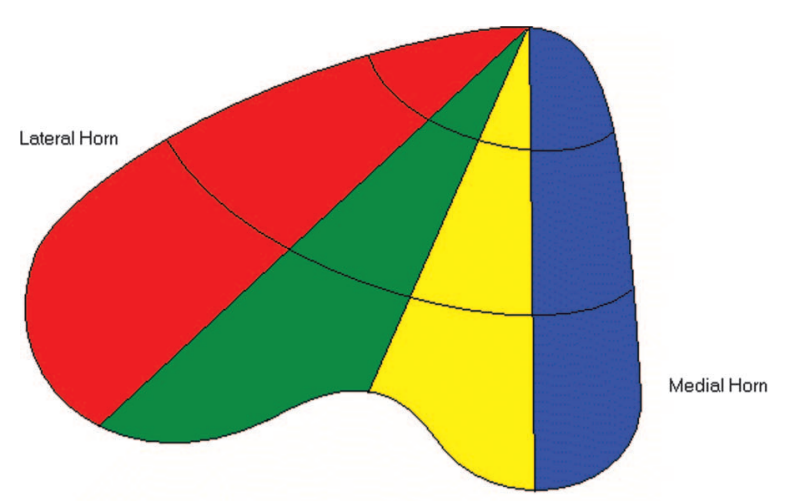

Representation of right visual field in the left LGB, seen in coronal section from behind.

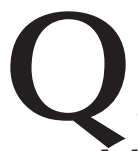
uadruple sectoranopias are wedge-shaped visual field defects that can be caused by lesions in the medial and lateral portions of the lateral geniculate body. ${ }^{1}$ By definition, there is involvement of two homonymous segments of each hemifield. The etiology is typically an occlusion of the anterior choroidal artery. Its counterpart, the horizontal sectoranopia, is produced by lesions of the geniculate hilum,

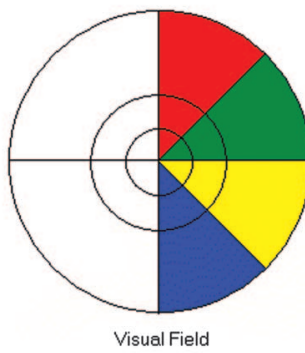

$\square$ Anterior Choroidal Artery
$\square$ Lateral Choroidal Artery
$\square \quad$ Lateral Choroidal Artery
$\square \quad$ Anterior Choroidal Artery an area supplied by the lateral choroidal artery (figure 1).

A 24-year-old man developed acute onset of blurred vision and headache. Examination revealed an isolated left homonymous hemianopia.

Brain MRI demonstrated acute intraparenchymal hemorrhage including the right lateral geniculate body (figure 2). Magnetic resonance angiography and cerebral angiogram showed abnormal
Figure 1. Anatomy of blood supply to lateral geniculate body. vessels in the right ambient cistern, suggestive of an arteriovenous malformation.

Humphrey 30-2 visual fields showed a left homonymous quadruple sectoranopia (figure 3 ).

\section{Reference}

1. Frisen L. Quadruple sectoranopia and sectorial optic atrophy: a syndrome of the distal anterior choroidal artery. J Neurol Neurosurg Psychiatry 1979;42:590-594.

From the Department of Neurology, University of Pennsylvania, Philadelphia.

Disclosure: The authors report no conflicts of interest.

Address correspondence and reprint requests to Dr. Steven L. Galetta, Department of Neurology, 3 Ravdin, Department of Neurology, University of Pennsylvania Hospital, Philadelphia, PA 19004; e-mail: galetta@mail.med.upenn.edu

Figure 2. T2 axial MRI demonstrating high signal abnormality involving the right lateral geniculate nucleus.

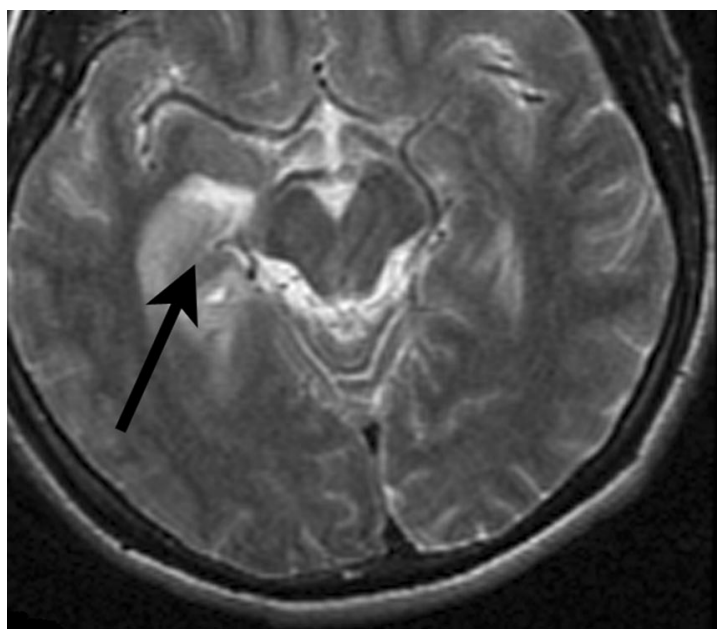

Copyright () 2006 by AAN Enterprises, Inc. E41 

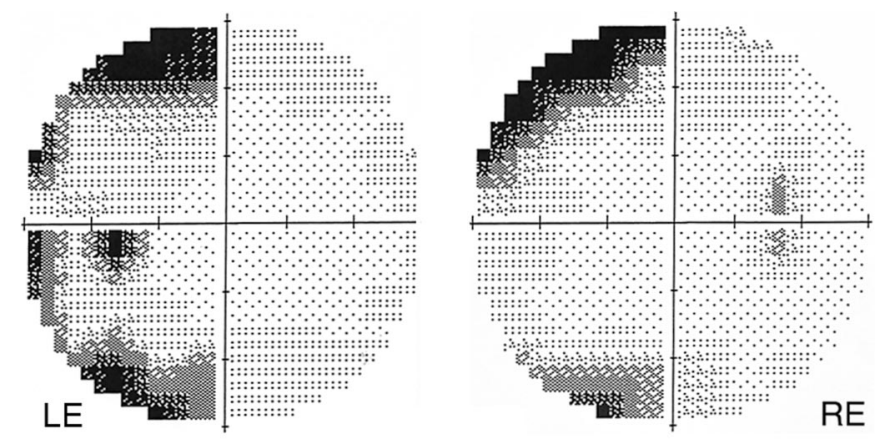

Figure 3. Humphrey visual field demonstrating left quadruple sectoranopia. 


\title{
Neurology
}

\author{
Geniculate quadruple sectoranopia \\ Benjamin J. Osborne, Grant T. Liu and Steven L. Galetta \\ Neurology 2006;66;E41-E42 \\ DOI 10.1212/01.wnl.0000219040.86961.2f
}

This information is current as of June 12, 2006

\section{Updated Information \& Services}

References

Subspecialty Collections

Permissions \& Licensing

Reprints including high resolution figures, can be found at: http://n.neurology.org/content/66/11/E41.full

This article cites 1 articles, 1 of which you can access for free at: http://n.neurology.org/content/66/11/E41.full\#ref-list-1

This article, along with others on similar topics, appears in the following collection(s):

All Neuro-ophthalmology

http://n.neurology.org/cgi/collection/all_neuroophthalmology Visual fields

http://n.neurology.org/cgi/collection/visual_fields

Visual loss

http://n.neurology.org/cgi/collection/visual_loss

Information about reproducing this article in parts (figures,tables) or in its entirety can be found online at:

http://www.neurology.org/about/about_the_journal\#permissions

Information about ordering reprints can be found online:

http://n.neurology.org/subscribers/advertise

Neurology ${ }^{\circledR}$ is the official journal of the American Academy of Neurology. Published continuously since 1951, it is now a weekly with 48 issues per year. Copyright . All rights reserved. Print ISSN: 0028-3878. Online ISSN: 1526-632X.

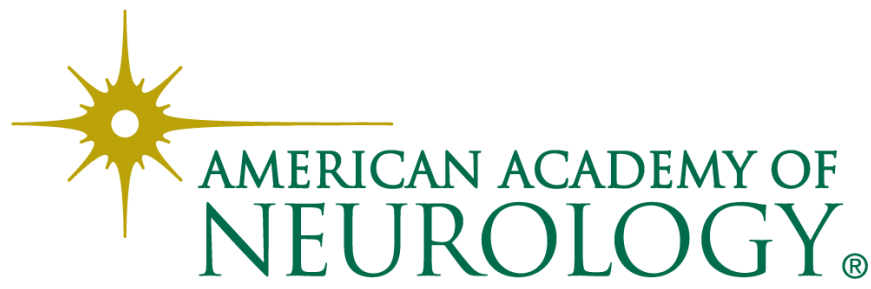

